\title{
Exploring the impact of changes in my practice on one pupil's learning in mathematics. Joseph - A case study
}

\begin{abstract}
This case study emerged from Action Research involving Year 2 pupils. The purpose of the research was to examine the effect that changing my practice had on my pupils' learning in mathematics. I focused on Joseph, a higher attaining pupil and explored how his behaviour changed as I began to change aspects of my teaching.

My research questions focused on tasks I provided for pupils, strategies they used to find solutions and my use of questioning to challenge their thinking. The data came from lesson observations, transcripts, samples of pupils' work and notes from my research diary. Qualitative methods such as theme and comparative analysis were employed to analyse the data using a grounded theory approach.

This case study does not claim that because one pupil experienced these changes they were experienced by all. It shows the changes that are possible when an environment of collaborative problem solving is created.
\end{abstract}

Keywords: action research, generalising, collaborative environment, strategies.

\section{Badanie wpływu zmiany sposobu nauczania matematyki na jednego z moich uczniów. Joseph - studium przypadku}

\begin{abstract}
Abstrakt
Analizowane studium przypadku powstało w ramach badania w działaniu obejmującego uczniów szkoły podstawowej, w wieku 6 i 7 lat. Celem tego badania było zmierzenie wpływu zmian moich praktyk nauczania matematyki na moich uczniów. W moich badaniach skupiłam się na uczniu o imieniu Joseph, który osiągał bardzo dobre wyniki w szkole, i zbadałam, jak jego zachowanie zmieniło się pod wpływem zmiany sposobu mojego nauczania. Moje pytania badawcze koncentrowały się na za-
\end{abstract}

Middlesex University, London. 
daniach, które przygotowywałam dla uczniów. Ponadto skupiłam się na strategiach używanych przez moich uczniów do znalezienia rozwiązań.

W pytaniach badawczych skoncentrowałam się na moim sposobie zadawania pytań, aby pobudzić uczniów do myślenia. Dane, wykorzystywane w badaniach, pochodziły z obserwacji lekcji, transkrypcji prac uczniów i notatek z moich badań. Metody jakościowe, takie jak analiza tematyczna i analiza porównawcza, zostały wykorzystane do analizy danych przy zastosowaniu podejścia metodologii teorii ugruntowanej.

To studium przypadku nie dowodzi zmiany, z uwagi na fakt, że doświadczył tych zmian jeden uczeń, nie wpływaliśmy poprzez zmianę na wszystkich uczniów. To studium przypadku pokazuje zmiany, które są możliwe, gdy współtworzone jest środowisko wspólnego rozwiązywania problemów.

Słowa kluczowe: badanie w działaniu, uogólnienie, współtworzone środowisko, strategie.

\section{Introduction}

This paper is part of a wider doctoral research project that took place over 4 years. It involved Action Research into how changes in my practice could improve my pupils' learning in mathematics. At the time of the research I was a class teacher of Year 2 pupils aged 6-7. This research arose out of my interest in problem-solving that I wished to investigate further. I was keen to consider any new and innovative strategies that would maximize the effectiveness of my teaching and further enhance my pupils' learning. Concerned about the perceived difficulties my young pupils experienced when applying their mathematical skills in other contexts, I believed that a more problem-based approach to the teaching and learning of mathematics would improve my pupils' understanding in this area. Therefore, I reflected on my practice through four action-reflection cycles using research questions that addressed the areas of reflective practice, teacher and pupil questioning and strategies pupils use to solve problems. Throughout this process, as I changed my teaching practice I noticed some changes in my pupils' behaviour and engagement in mathematics lessons. I focused in particular on one pupil who appeared to undergo the most significant changes over the course of a year and studied him in more detail as a special case. The use of the case study method allowed me to explore in more detail the impact of changing my practice on one particular pupil.

\section{The Case Study Method}

The case study method is widely considered by researchers such as Michael Bassey (1999), Louis Cohen, Lawrence Manion and Keith Morrison (2005) and Robert Yin (2009), to be an appropriate strategy in educational research. According to Yin 
(2009), when to use case study research is dependent on the types of questions being asked, the amount of control the researcher has over events taking place, and whether these events are occurring in real settings.

There are many definitions as to what constitutes a case study depending on the literature one reads. Barry Macdonald and Rob Walker (1974: 1) define it as the "examination of an instance in action". Bassey (1999) refers to it as 'the study of a singularity conducted in depth in natural settings' (ibidem: 47) 'which is chosen because of its interest to the researcher' (ibidem: 75). Martin Denscombe's (2005: 30) states that a case study is when a "spotlight is focused on individual instances rather than a wide spectrum". Yin (2009) defines it as 'an empirical inquiry that investigates a contemporary phenomenon in depth and within its real-life context, especially when the boundaries between phenomenon and context are not clearly evident' (ibidem: 18).

John Gerring (2007) claims that it is difficult to define case study but that

it may be understood as the intensive study of a single case where the purpose of that study is - at least in part - to shed light on a larger class of cases (a population) (ibidem: 20).

What these definitions have in common is the fact that a case study focuses in on a single case, which makes it one of its defining characteristics. Other significant characteristics include the fact that case study research occurs in real settings and does not rely on experimental situations. Because it focuses on a singular case, the research can take a more in-depth and detailed look at that particular case rather than having to deal with a wider field. An advantage of using a case study is the fact that the researcher is not restricted to using one method, but instead is free to choose whatever they feel best fits their research. Using a variety of methods is considered by Robert Stake (1978) and Denscombe (2005) to be a strength of case studies as it allows for triangulation of the data which increases the validity of the research.

There are a number of weaknesses associated with case study research, one of which, according to Yin (2009), is a lack of rigor. The researcher must ensure that they collect and analyse the data carefully, following procedures rigorously and ensuring that they try to avoid being biased when interpreting the findings. Another weakness of case study research is that it is considered to be time consuming not only in the collection and analysis of the data, but also in writing the report, the end result often being a report which is deemed too difficult to read. A third disadvantage of using case studies is the inability of the researcher to generalise scientifically from the research findings. 


\section{Generalising in case studies}

One of the paradoxes of case study research examined by Helen Simons (1996) is that it attempts to generalise to the wider situation by focusing on a particular case. Denscombe (2005: 30) described it as aiming "to illuminate the general by looking at the particular" Cohen et al. (2005) claimed that it tries

to probe deeply and analyse intensively the multifarious phenomena that constitute the life cycle of the unit with a view to establishing generalisations about the wider population to which that unit belongs (ibidem: 185).

Attempting to generalise from the particular is a weakness of case study research because it calls into question how representative of the wider field a single case could be. Stake (1978) made this point when he stated that

a case is often thought of as a constituent member of a target population. And since single members poorly represent whole populations, the case study is seen to be a poor basis for generalisation (ibidem: 7).

Jennifer Rowley (2002: 25) questioned whether generalising from a case study was necessary and wondered if the case study could be left to be 'interpreted' by the reader and taken 'into their own experience'. Her point echoed that made by Stake (1978: 5) when he claimed that case studies 'may be epistemologically in harmony with the reader's experience and thus to that person a natural basis for generalisation'. He called this naturalistic generalisation where the reader can see similarities between the case study and their own situation.

There are as many types of case study as there are definitions of it and the type being used here is that referred to by Bassey (1999) and Yin (2009) as the descriptive case study. This provides a 'narrative account' (Cohen et al. 2005) of the case and attempts to tell the story of what has happened. It does not attempt to test theories or make any judgements as to what the findings show. What follows is the story of Joseph ${ }^{1}$ and the changes that occurred in his learning as I changed my practice. It is not being presented as an example of how my practice changed the learning habits of all my pupils, nor is it claiming any generalisation in a wider context. It is instead a descriptive account of one pupil's experience which interested me and which I hope will also engage the reader.

1 Joseph was the pseudonym which he chose for himself. 


\section{Why choose Joseph?}

There were some pupils who caught my attention as I watched their development over the year, one of whom was Joseph. I chose him out of the others because of the obvious changes I had observed in him as I changed my practice and also because of the amount of data I had collected about him. Joseph came into my class at the beginning of the year seemingly very confident and self-assured of his abilities. He did not like to share tasks with others, preferring instead to work independently and was often quite dismissive of the efforts of others. He did not like to be corrected about his work especially by his peers and believed his ways were better. By the end of the year I perceived a change in Joseph's behaviour as he became a much more co-operative member of the group who was now willing to share his ideas with others and was more open to those of his peers. This made him an ideal candidate for a small case study. Stake (1995) believed that having an intrinsic interest' in a case was a legitimate reason for its choice.

\section{Background}

In focusing on Joseph as a particular case I used evidence collected from lessons recorded at regular intervals during the academic year. At the time of data collection the idea of including a case study in my research had not been part of my plan, but instead arose during my analysis of the data. Although Joseph was not always part of the focus group in every lesson, he actively contributed to whole class discussions and I often called on him to answer questions during the course of lessons.

Joseph was one of the oldest pupils in the class, celebrating his birthday at the beginning of September. He came from a single parent family with much older siblings who no longer lived at home. Joseph was a high attaining young boy, expected to achieve high levels in all areas of the end of Key Stage 1 assessments and was considered by many other pupils in the class to be the 'cleverest'2. He completed most tasks confidently, preferring to work independently, without assistance from anyone. One might argue that being able to work independently was a positive attribute for a seven year-old and that our aim is to encourage all pupils to develop as independent learners. However, it was not that straightforward with Joseph. He appeared to view working collaboratively in a negative way, as if it signified that he needed help in order to complete the task, which to him seemed to be a sign of not being 'clever enough'.

My decision to carry out a case study of Joseph occurred during the summer holidays when Joseph had left Year 2 and moved schools, so there was no possibil-

\footnotetext{
2 Being clever or smart were terms used by the children when describing each other's perceived 'ability'.
} 
ity of involving him in any further data collection. Having analysed the data and categorised the themes, I revisited them with Joseph in mind. The following section describes the outcomes of that data analysis.

\section{Data Analysis}

Data for the original Action Research project had been collected using both qualitative and quantitative methods, namely observations, field notes, research diary and samples of pupils' work. These different methods of collection helped to triangulate the data in the later stages of the analytic process and to validate the research. The analysis was carried out by means of a grounded theory approach as discussed by Juliet Corbin and Anselm Strauss (2008), Denscombe Martyn (2005) and Sevasti-Melissa Nolas (2011). Open and axial coding were used to locate themes within the data and relate themes and categories to each other through theme analysis. Comparisons were made between categories and incidents that occurred in all of the data and questions asked in order to develop a greater understanding of the developing concepts (Corbin J., Strauss A. 2008; Denscombe M. 2005; Sevasti-Mellisa Nolas 2011).

When I decided to focus on Joseph as a particular case, I separated the sections of the lesson transcripts which contained data relating to him, thus allowing me to focus in particular on his interactions. I examined these data using the themes which emerged from the original analysis and wrote memos (Herbert A., Feldman A., Posch P., Somekh B. 2008), noting any significant details and outlining my interpretations of them. I then separated the data into categories, which examined

- Instances when Joseph worked independently,

- Instances when he collaborated with others,

- Strategies he used to solve problems,

- How he explained his reasoning.

I related these findings to what I had noted from earlier analysis of the data as a whole and what follows is my interpretation of Joseph's learning experience through the year based on these findings.

\section{Working Independently}

Evidence from the data shows that at the beginning of the year Joseph preferred to work independently on tasks and this was true in other subjects as well as in mathematics. According to Merrilyn Goos, Peter Galbraith and Peter Renshaw (2004), it is not uncommon for some pupils to resist their teacher's attempts to involve them in 'communities of practice', but it is up to the teacher to ensure they participate in some way even if it is only marginal. Joseph made it clear to everyone 
including me that he did not wish to share resources or work with a partner. This was evident in his often sullen and dismissive behaviour towards the partners with whom he had to work. The following extract from a lesson recorded at the beginning of the academic year is an example of how Joseph interacted with his peers when he first came into my class.

Joseph: We're not telling you, we're not telling you our answer.

Angela: I did it before, because I did it before.

Joseph: because I said it. I said, the answer

Angela: I knew the answer already.

Joseph: What is it?

Angela: 5

Joseph: No!

Angela: Yeah!

Joseph: Hah, hah! No! There are only 4 bowling pins, so you don't know. Hah hah hah!

Joseph was unwilling to share his work with others at his table. He appeared to derive pleasure from what he perceived to be an error by Angela and was disparaging of her efforts. Let us contrast this to what happened in the next extract when Joseph himself made an error.

Joseph: Actually you don't need your pencil either. I'm going to work... okay, the final $2 \ldots$ to score 6.

Jack: Why are you going... why are you doing 3 and 4 ?

Joseph: To score 6

Jack: $\quad$ Because that will make 7.

Lexa: $\quad$ Now we choose 4 and 2 to make 6.

Joseph: No, see, we found the 5 .

Joseph: Now we do 6, easy!

Lexa: What are you doing?

Joseph: No real answers.

Jack: It doesn't matter because we're doing it.

Joseph: Yeah yeah! But you've not written anything yet.

Jack: Yes, we have.

Joseph: No you haven't, let's see!

Jack: You're not supposed to write it on the bottom.

Lexa: You don't understand it.

Joseph: Yes, you are!

Jack: No!

Joseph: You are!

Joseph's miscalculation was pointed out by Jack without any obvious criticism or judgement, which was in contrast to the way Joseph behaved towards Angela. Joseph did not make any comment in reply, but instead criticised Jack's method of 
recording his answers. Was this a way of deflecting attention from the fact that he had been seen to make an error by one of his peers? Joseph seemed to resent being given advice or assistance by his peers and appeared to be more 'ego oriented', demonstrating aspects of a superiority complex as described by John Nicholls, Paul Cobb, Terry Wood, Ema Yackel and Michael Patashnick (1990). He often replied with comments such as, Mind your own business or Don't tell me what to do, when others in his group tried to offer help. Was he afraid of how it would affect his standing among his peers if he was seen to need support? Requests from his partners for assistance were met with equal disdain as the following extracts demonstrate.

Jack: How do we write anything we use to help you?

Joseph: I don't know. I'm not you.

Charlie: Do you know how to spell hours?

Rose: I do.

Joseph: Everyone has (?), He doesn't know how to spell it.

Charlie: Do you know how to spell hours?

Joseph: Hee! Charlie doesn't know how to spell it.

Charlie: Do you know how to spell hours?

Joseph: Charlie doesn't know how to spell it.

Rose: He does!

Joseph: Charlie doesn't

?: $\quad$ Easy! H...o...u........s

Joseph: He doesn't! Remember when you asked us how do you spell hours?

?: $\quad$ He didn't

Joseph: He did, he did!

Rose: When we were in Reception, he told me how to spell hours, so he does.

Joseph: So how come he just told me? Yeah! You don't know... he asked me how do you spell hours. That's really silly.

Joseph: You don't know how to spell hours.

Charlie: I just saw the word and I knew how to spell it straightaway.

Joseph's reaction to Charlie's request for help with spelling, a request which had not been directed at him but at Rose prompted her to come to his defence. Joseph knew how to spell the word, so why did he have this uncooperative behaviour towards his peers and unwillingness to assist them when asked? His initial reaction appeared to be one of disdain, again highlighting his 'ego orientated' outlook, but when this behaviour was challenged, he became more supportive and helpful.

Joseph: 12 plus $10 \ldots$ hah! 12 plus 10

Jack: 12 take away 10

Joseph: You don't do... (?) You're wrong, you're wrong, you're actually wrong.

Jack: No, but we need to show...

Joseph: Okay, let's cross it out. 
Despite the fact that Jack was his partner and they were meant to be working together, Joseph was disparaging of Jack's strategy for working out the answer to be 2 o'clock by subtracting 10 from 12 . He did not offer any advice or assistance to Jack to correct his error until later in the lesson when challenged by me to help his partner. He then explained to Jack where he had made his mistake and what he could do to correct it. His behaviour in this instance was more supportive of his partner as the following extract shows.

Teacher: Can you explain to me why you said... take away 10 if you're talking about time?

Jack: $\quad$-..

Teacher: What do you think Joseph? Do you think that was a good way of working it out?

Joseph: (Shakes his head)

Teacher: Why not?

Joseph: Because that means something else. It was a little bit silly. You can't make time go backwards.

Teacher: I thought you were working with him. Yes, so he's having trouble with this one. Can you explain to him how you worked it out to help him to work it out? Yes?

Joseph: If we have 12 take away $10 . .$. that wouldn't... you were a little bit right but... instead of...

Joseph: You were a little bit right, but time can't go back. So 12 take away 10 equals, 2 o'clock. It's a magic 2 o'clock in the afternoon. What your... what it actually... if we took away 10 it would be 2 o'clock in the morning, which...

Joseph: Well, you should have said, 12 plus... so did you do a plus? You should just have done a plus... 12 plus 2 .

As the year progressed Joseph became more co-operative and willing to share his ideas with his partners and there were fewer instances where he ridiculed the efforts of others. It appeared he was becoming more 'task oriented' as described by Nicholls et al. (1990) and was therefore more concerned with task completion than with being superior to his peers.

Further evidence highlights the lack of collaboration evident among the pupils. On the surface they may have appeared to be working together on tasks, but closer inspection showed that they were just being independent together. In the following transcript extract Joseph appeared to have the dominant role and was telling Adam what he should do, as opposed to working with him to make up their subtraction problems together.

Joseph: Daniel... gave him...

Joseph: Adam

Adam: ?

Joseph: Just write that. Write it!

Joseph: Jack had... 4... toys, 4 toy guns. 
Joseph: Daniel... gave him...

Joseph: Adam, you know, you don't have to write that... Adam you don't have to write... Jack had 4 toy guns and Daniel gave him 6 more. How many toy guns has he got altogether?

Adam: Hee hee hee! There might be a rainbow.

Joseph: No there isn't going to be a rainbow.

Joseph: Don't do it like that.

Joseph: You should know

Adam: 10

Joseph: You don't know your number bonds to 10.

Adam: 70

In this extract it appeared that Adam had his own ideas about what he should be doing, which did not seem to match Joseph's. It is not evident from the data whether Adam complied with Joseph's wishes or carried on with what he was doing, but it is clear that they were not collaborating or sharing their ideas in relation to the task in question.

\section{Collaborating with Others}

By the end of the year there was a noticeable change in the way Joseph worked. He was far more willing to share his thinking and was not as disparaging of his friends' work as he had been. This change did not happen overnight but was a gradual process that seemed to come about unnoticed. It was more obvious with Joseph than many of the other pupils because of his initial opposition to working with a partner from the outset. The transcript extract that follows demonstrates the extent to which Joseph's behaviour had changed.

Joseph: Look let's do it... let's try 17

Jack: ?

Joseph: Let's try 17 and see... No way... 4, 8, 12, 16

Jack: Now let's sort the threes... Let's leave them.

Joseph: Okay, let's go with 20

Joseph: We know it works in fours. We know it works in fives, we don't know if it works in threes and it doesn't.

Jack: $\quad$ Remember, we have 8 here +3

Joseph: Cross off 20, the answer is not 20

Jack: $\quad$ There's 30, 29, 28, 27, 26, 25, 19... 21

Joseph: Let's try out 19

Jack: Yes, it's not 16

Joseph: No, it's not $19 . .$. let's try... let's try 21.

Jack: It could never be 21

Joseph: It's not $16 \ldots$... let's try 29 


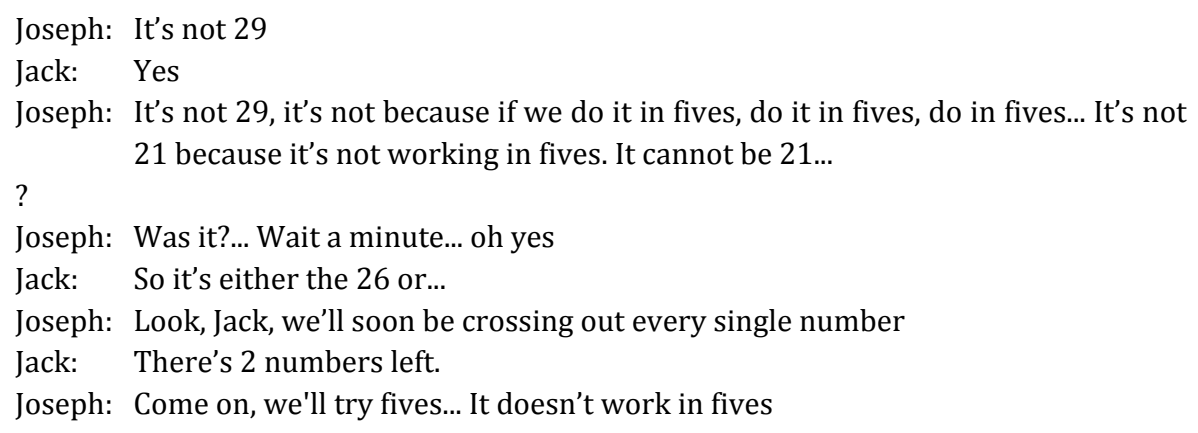

Joseph is clearly engaged in dialogue with Jack about the problem on which they are both working. They are very much 'task oriented' as described by Nicholls et al. (1990), which is in contrast to the 'ego oriented' attitude discussed earlier. There is no evidence of either one competing or trying to be dominant, but instead both appear to be engrossed in the task and concerned only with finding the solution to the problem. What brought about this change in Joseph's behaviour? Had he just developed in maturity over the year? Did he find the introduction of more challenging tasks stimulating? Had he now become used to interacting with his peers in a more collaborative environment as described by Goos et al. (2004)? I believe that it was not any singular one of these reasons but an amalgamation of all of them that brought about the change in Joseph.

Comments such as: I've got an idea let's do 3 rows of tiles and Me and Jack we started off by thinking what the answers could be demonstrate how Joseph viewed his relationship with his peer as a partnership in which they both had a role to play. His use of let's and me and Jack is inclusive and highlights the fact that he was no longer working independently but was co-operating with someone else.

Earlier in the year it appeared that Joseph regarded seeking assistance as a sign of weakness or lack of 'ability'. He would not share his ideas with others and criticised those who pointed out his errors. Later in the year Joseph was heard making comments such as:

What? What do we have to do?

We don't have the answer,

So, how many threes do we have to do?

What I'm thinking is ...

It appears from these comments that Joseph no longer felt the need to be dominant and to constantly be 'correct' in front of others. He was not threatened by the fact that he was not clear about what to do and appeared happy to share his thinking with others. This echoes the point made by Goos et al. (2004: 94) that pupils seek 'assistance from peers and the teacher where a culture of collaboration has been established.' 


\section{Strategies Used}

The strategies Joseph used early in the year consisted mostly of knowledge of number facts. Extracts from lesson transcripts demonstrate this as follows

Joseph: 1 and 4, 3 and 2, 2 plus 4, 3 plus 1 plus 2, 1 plus 2 plus 4, 3 plus 4 .

Joseph: 15 minutes is half... is half of 30.30 is half of 60

He was secure in his knowledge of addition, subtraction and some multiplication facts and he demonstrated an ability to use these appropriately when solving simple problems. He can, however, be heard using a range of counting strategies towards the end of the year as the following extracts demonstrate.

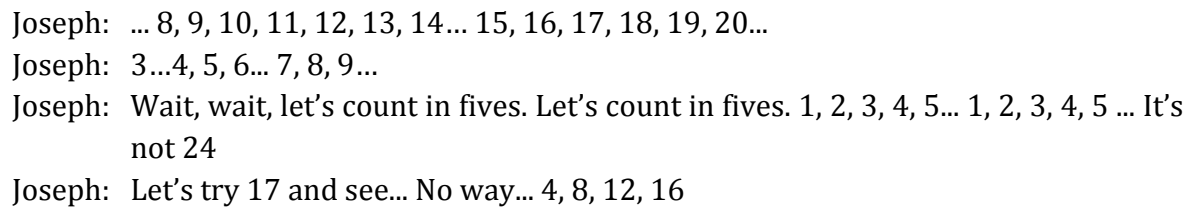

These examples show Joseph not only using what Thomas Carpenter, Ellen Ansell, Megan Franke, Elizabeth Fennema and Linda Weisbeck (1993), Thomas Carpenter and James Moser (1984), Joanne Mulligan and Jane Watson (1998), Walter Secada, Karen Fuson and James Hall (1983) and Ruth Steinberg (1985) consider to be the basic counting-all strategy, but also using the more progressive strategies of rhythmic and step counting described by Julia Anghileri (1989) and Mulligan and Watson (1998). One might find this unusual given Joseph's knowledge of number facts, but it demonstrates the point that all children will use counting-all as a strategy, regardless of their level of attainment and their ability to count at a higher level. Although he used number facts quite confidently at the beginning of the year, Joseph's mental recall of multiplication facts and the derived division facts was much more secure by the end of the year, enabling him to answer questions involving larger numbers more confidently.

The most notable development over the year was Joseph's use of what John Mason (1999) acknowledges as higher order skills of specialising and generalising that shows a deeper understanding of mathematics. There was no evidence of either of these strategies earlier in the year and the fact that there were more instances of both at the end of the year may have been due to the fact that both the change in mathematical activities and teacher questioning encouraged pupils to engage in such behaviour. I developed my use of open-ended questions because research by Kenneth Tobin (1987) highlighted the importance of asking higherorder cognitive level questions in order to develop pupils' cognitive thinking. However, if the task involved is at a low cognitive-level, then it makes it difficult for 
teachers to engage in higher-order questioning, which in turn reduces pupils' higher cognitive thinking. Mark Kilpatrick (2003), Amy Martino and Carolyn Maher (1999) and Paul Sullivan, Elizabeth Warren and Paul White (2000) suggested tasks should be open-ended to allow for extended pupil thinking and teacher questioning. I provided pupils with more rich, challenging tasks which enabled them to reason mathematically and make conjectures as they sought solutions. Tasks were now chosen because they specifically provided pupils with opportunities to find patterns and make generalisations, which had not previously been the case. This change in task provision is supported by the views of Thomas Carpenter and Linda Levi (2000), James Kaput and Maria Blanton (1999), Michael Mitchelmore (2002) and Rina Zazkis, Peter Liljedahl and Egan Chernoff (2008) who discuss the importance of providing opportunities which enable pupils to make their own generalisations. Joseph was given this opportunity through the provision of rich mathematical tasks which were open-ended and more conducive to developing reasoning skills.

In this extract Joseph selected a specific number to test it as a multiple of 3,4 or 5 .

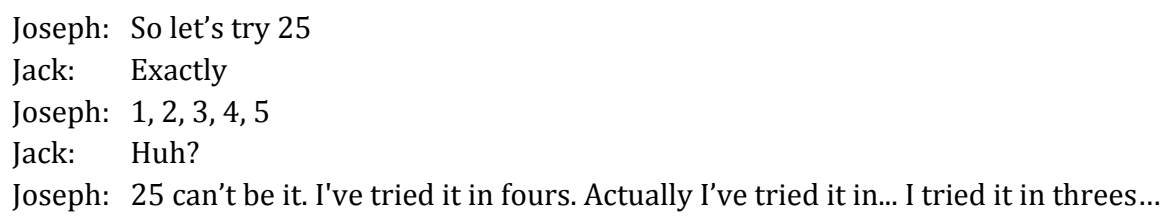

After specialising with other numbers Joseph then went on to express a generalisation as follows.

Joseph: Because if we did it in fours last we would have to have an even number and 29 is an odd number

Later when asked to generalise about the answer he made the following statement.

Joseph: It is in the 3 times tables, and the 4 times tables and it is not in the 5 times tables.

He later expressed this more accurately as: 24 is a multiple of 3 and a multiple of 4 , but it is not a multiple of 5. His earlier incorrect generalisation that the answer was a multiple of 5 was caused, I believe, by the fact that he became distracted by the pattern of $3 \mathrm{~s}, 4 \mathrm{~s}$ and $5 \mathrm{~s}$. He appeared to forget that if the shells were grouped in $5 \mathrm{~s}$ there would be a remainder of 4 . This is an example of what Dave Hewitt (1994) refers to as 'train spotting' and is possibly what prevented Joseph from finding the answer earlier in the lesson, as the following extract shows. 
Joseph: Wait, wait, let's count in fives. Let's count in fives. 1, 2, 3, 4, 5... 1, 2, 3, 4, $5 \ldots$ It's not 24

Jack: $\quad$ But if you do... (?)

Joseph: If we do it in fives... yeah, that works in fives and it has to work in fives in threes and in fours.

Joseph: So we cross off 24 .

An extract from a lesson recorded the previous week also demonstrates Joseph's ability to generalise.

Joseph: If the pattern starts on one, they are all odd numbers. If it starts on 2 they are all even numbers.

As well as highlighting the instances when Joseph made generalisations, they also show how he was able to explain his reasoning when asked.

\section{Explaining Reasoning}

At the beginning of the year Joseph appeared to have difficulty explaining why he chose certain strategies, as the following extract shows.

Teacher: Okay how did you do it?

Joseph: We did it by adding. We added them

Teacher: Why did you add them?

Joseph: Because we didn't have enough numbers to take away.

He did not seem to have had much experience of justifying or defending his answers at this stage of the year and what he said did not relate to the strategy he used or the problem he had to solve. It was clear from Joseph's interactions during the lesson that he understood the need to combine the numbers to work out the answers. Because of this I found it difficult to understand why he mentioned the possibility of subtracting. In the following example Joseph again fails to give a clear reason as to why he chose that particular strategy.

Teacher: This time year 1, go on the playground. They go out at 11 o'clock. They come back in at 12 o'clock. How long have they been on that playground? Joseph

Joseph: one hour.

Teacher: How do you know?

Joseph: Because 11 plus 1 would equal 12. But if... because if you added an extra one... if you added an extra one it would just give you 1 o'clock.

Teacher: Why did you add an extra, an extra hour?

Joseph: Because the (?) helps you get the answer a little bit easier. 
He did not appear to link the reason for his choice of strategy with what the problems were asking. As the year progressed, Joseph's explanations of his reasoning became clearer and more pertinent to the problem he was solving.

Teacher: Why did people count in twos? Joseph

Joseph: Because a pair is 2 .

Joseph: It can't be 23 because $18+3$ equals 21 .

Joseph: We know that the answer is not 23 , because when we group in threes we don't get 23, we get 21 .

Teacher: Did you try clue number 4 with 29?

Joseph: No.

Teacher: Why not?

Joseph: Because if we did it in fours last we would have to have an even number and 29 is an odd number

The last extract demonstrates how Joseph's explanations had, by the end of the year, become more sophisticated and their relevance to the task was clear. I believe that this was due to the collaborative environment which had been established in class. It is further supported by the research of Sylvia Rojas-Drummond and Neil Mercer (2003), Neil Mercer and Claire Sams (2006) and Rupert Wegerif, Karen Littleton, Lyn Dawes, Neil Mercer and Denise Rowe (2004) who highlighted the positive effect on reasoning and interaction that occurred when pupils were encouraged to share their reasoning with others.

\section{Summary}

My reason for including Joseph as a case study was to highlight the changes that one pupil experienced throughout the year. Joseph moved from being an uncooperative and ego-oriented pupil to being one who was more focused on the task and therefore willing to collaborate with others in order to reach an outcome for that task. His ability to explain his reasoning had also improved by the end of the year and he could clearly demonstrate an understanding of why he used certain strategies to solve problems. Joseph had also acquired higher order skills of specialising and generalising by the end of the year, showing a greater understanding of the mathematics with which he had engaged.

The changes that occurred with Joseph were, I believe, directly linked to the changes I introduced in my practice. I provided more challenging mathematics tasks in a collaborative environment where pupils were encouraged to focus on the strategies and explain their reasoning. The questioning I used developed deeper thinking skills and encouraged pupils to consider alternative approaches to solving problems and to make generalisations. Comparisons of the themes which emerged from the data collected through lesson observations, my research diary, pupils' 
work samples and discussions supported this claim and it was evident in later lessons that pupils had developed greater confidence and deeper engagement with mathematics than they had done in previous years. Joseph's change of behaviour towards collaboration with his peers and engagement with mathematics was more obvious which is why I chose him as a particular case.

This case study does not however claim that because one pupil experienced these changes they were experienced by all pupils. On the contrary, there were a number of pupils who were already confident about working collaboratively with others and continued to do so throughout the year. There were also one or two pupils who could only work with certain partners and not others. Although the ability to explain their reasoning improved for the majority of pupils, there were a number who still found it difficult to explain what strategy they had used and why. An important point to note is that pupils of Joseph's age continue to develop socially and emotionally over time. This must also be taken into account when comparing changes in behaviour and will have influenced to some degree the changes exhibited by Joseph. The challenge is in measuring the degree of impact of social maturity over the impact of pedagogical changes on pupils' learning in mathematics. Such measurement was beyond the scope of this study and is a consideration for future research.

No attempt at generalising in any wider context is being made through this case study, which according to Stake (1978) would be inadvisable unless it was a naturalistic generalisation where the reader could see similarities between the case study and their own situation. What this case study shows is the changes that are possible when an environment of collaborative problem solving is created. That is not to say that they will always occur in similar situations, but simply that the possibility exists. It also highlights the fact that very young children have the ability to make generalisations in mathematics. It does not imply that all young children will be able to generalise, but that the potential is there if they are given the opportunity to do so.

\section{References}

Altrichter R., Feldman A., Posch P., Somekh B. (2008) Teachers Investigate their Work (2 ed.), London, Routledge.

Anghileri J. (1989) An Investigation of Young Children's Understanding of Multiplication, "Educational Studies in Mathematics", 20: 367-385.

Bassey M. (1999) Case study research in educational settings, Open University Press.

Carpenter T. P., Ansell E., Franke M. L., Fennema E., Weisbeck L. (1993) Models of Problem Solving: A Study of Kindergarten Children's Problem-Solving Processes, "Journal for Research in Mathematics Education", 24: 428-444. 
Carpenter T. P., Levi L. (2000) Developing conceptions of algebraic reasoning in the primary grades, Res. Rep. 00-2.Univ. Madison, WI: National Centre for Improving Student Learning and Achievement in Mathematics and Science.

Carpenter T. P., Moser J. M. (1984) The Acquisition of Addition and Subtraction Concepts in Grades One through Three, "Journal for Research in Mathematics Education", 15: $179-202$.

Cohen L., Manion L., Morrison K. (2005) Research Methods in Education, London, Routledge Falmer.

Corbin J., Strauss A. (2008) Basics of Qualitative Research (3 ed.), London, Sage Publications Ltd.

Denscombe M. (2005) The Good Research Guide, Maidenhead, Open University Press.

Gerring J. (2007) Case study research: principles and practices, Cambridge University Press.

Goos M., Galbraith P., Renshaw P. (2004) Establishing a community of practice in a secondary mathematics classroom in: B. Allen, S. Johnston-Wilder (eds.), Mathematics Education: Exploring the Culture of Learning, Falmer Pr.

Herbert A., Feldman A., Posch P., Somekh B. (2008) Teachers Investigate Their Work: An Introduction to Action Research Across the Professions, 2nd Edition, New York, Routledge.

Hewitt D. (1994) Train spotters' paradise, “Teaching Mathematics": 47-51.

Kaput J., Blanton M. (1999) Algebraic reasoning in the context of elementary mathematics: making it implementable on a massive scale, https://files.eric.ed.gov/ fulltext/ED441663.pdf

Kilpatrick M. (2003) Why did you say right angles?, The place of questioning in mathematics, ACE Papers,https://researchspace.auckland.ac.nz/bitstream/handle/2292/ 25116/ACE_Paper_5_Issue_12.pdf?sequence=1

Macdonald B., Walker R. (1974) Case-study and The Social Philosophy of Educational Research, "Cambridge Journal of Education", 5 (1): 2-11.

Martino A. M., Maher C. A. (1999) Teacher Questioning to Promote Justification and Generalization in Mathematics: What Research Practice Has Taught Us, "The Journal of Mathematical Behavior", 18: 53-78.

Mason J. (1999) Learning and doing mathematics, (2 ed.), York, QED.

Mercer N., Sams C. (2006) Teaching children how to use language to solve maths problems, "Language and Education", 20 (6): 507-528. 
Mitchelmore M. C. (2002) The role of abstraction and generalisation in the development of mathematical knowledge, "Mathematics Education for a KnowledgeBased Era", 2: 157-167.

Mulligan J., Watson J. (1998) A developmental multimodal model for multiplication and division, "Mathematics Education Research Journal", 10: 61-86.

Nicholls J. G., Cobb P., Wood T., Yackel E., Patashnick M. (1990) Assessing students' theories of success in mathematics: Individual and classroom differences, "Journal for Research in Mathematics Education", 21: 109-122.

Nolas Sevasti-Melissa (2011) Grounded theory in: Frost Nollaig (ed.), Qualitative Research Methods in Psychology: Combining Core Approaches, Maidenhead, Open University Press: 16-43.

Rojas-Drummond S., Mercer N. (2003) Scaffolding the development of effective collaboration and learning, "International Journal of Educational Research", 39: 99-111.

Rowley J. (2002) Using case studies in research, "Management Research News", 25 : $16-27$.

Secada W. G., Fuson K. C., Hall J. W. (1983) The Transition from Counting-all to Counting-on in Addition, "Journal for Research in Mathematics Education", 14: 47-57.

Simons H. (1996) The paradox of case study, "Cambridge Journal of Education", 26.

Stake R. E. (1978) The Case Study Method in Social Inquiry, "Educational Researcher", 7: 5-8.

Stake R. E. (1995) The art of case study research, Sage Publications, Inc.

Steinberg R. M. (1985) Instruction on Derived Facts Strategies in Addition and Subtraction, "Journal for Research in Mathematics Education", 16: 337-355.

Sullivan P., Warren E., White P. (2000) Students' responses to content specific openended mathematical tasks, "Mathematics Education Research Journal", 12: 2-17.

Tobin K. (1987) The Role of Wait Time in Higher Cognitive Level Learning, "Review of Educational Research", 57: 69-95.

Wegerif R., Littleton K., Dawes L., Mercer N., Rowe D. (2004) Widening access to educational opportunities through teaching children how to reason together, “Westminster Studies in Education", 27 (2): 143-156.

Yin R. K. (2009) Case study research: Design and methods, 4th ed., Thousand Oaks, Sage Publications, Inc.

Zazkis R., Liljedahl P., Chernoff E. J. (2008) The role of examples in forming and refuting generalizations, "ZDM Mathematics Education", 40: 131-141. 